\title{
JOURNAL.RU
}

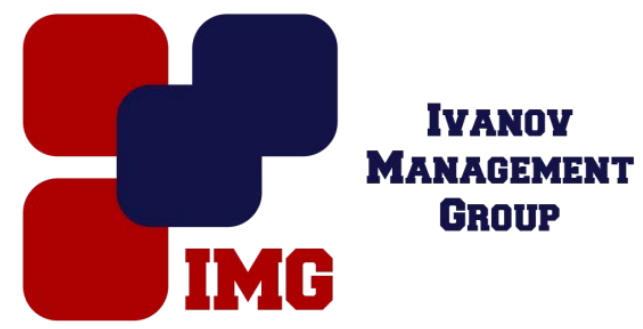

Купцова Ю.А. Белгородский научный исследовательский государственный университет Белгород, Россия

doi: 10.18411/lj-30-11-2016-3-10

idsp 000001:lj-30-11-2016-3-10

\section{К вопросу определения и типологии дискурса}

\section{Аннотация}

В данной статье рассматриваются различные дефиниции термина «дискурс», предлагаемые отечественными и зарубежными лингвистами. Различные толкования дискурса влекут за собой соответствующие его типологии. Анализируются некоторые из них, получившие широкое освещение в научной лингвистической литературе.

Ключевые слова: дискурс, дифиниция дискурса, текст, типы дискурса

В рамках лингвистического анализа основным объективным признаком, который определяет ценностную сторону высказывания, является дискурс. Данное понятие получает множество разных интерпретаций в современных лингвистических исследованиях.

Согласно «Лингвистическому энциклопедическому словарю», дискурс это «связный текст в совокупности с экстралингвистическими, прагматическими, социокультурными, психологическими и другими факторами; текст, взятый в событийном аспекте; речь, рассматриваемая как целенаправленное социальное действие, как компонент, участвующий во взаимодействии людей и механизмах их сознания» [1].

Термин «дискурс» сначала применялся в значении, который в русской лингвистике был близок термину «функциональный стиль» языка или речи. Согласно трудам В.В. Виноградова, «функциональный стиль» означал особый тип текстов: газетных, обиходных, деловых и т.д., а также характерную для каждого типа лексическую и грамматическую наполненность. Ю.С. Степанов отмечает, что для зарубежных лингвистов дискурс означал «данность текста», то есть сам текст. Позже зарубежные исследователи пришли к выводу, что «дискурс» означает не только «данность текста», но и систему, находящуюся за этой данностью, прежде всего грамматику. По мнению ученого, «дискурс - это новая черта в облике языка, каким он предстал перед нами к концу XX века» [2]. 
В трудах Т.А. Ван Дейка и В. Кинча превалирует «текстовый» подход. Тексты рассматриваются как «речевые произведения, которых великое множество, может быть, множество неисчисляемое, и поэтому они требуют выработки лишь общих принципов для своего понимания (для своей грамматики, но не реальных конкретных грамматик разных типов дискурса»). Т.А. Ван Дейк представляет дискурс как иерархически организованную целую структуру, которая определяется в качестве системы дискурсивных целей. В процессе осмысления текста происходит «свертывание смысловой структуры в макроструктуру, которая служит кратким выражением содержания текста» [3]. Позже ученый рассматривает дискурс в рамках коммуникации, он учитывает не только структурный параметр, но и социально-психологичекие и когнитивные аспекты. Дискурс определяется лингвистом не только в качестве вербального объекта, но и как форма социального взаимодействия. Дискурс «не ограничивается рамками конкретного языкового высказывания, т.е. рамками текста, а включает в себя говорящего, адресата, их личностные и социальные характеристики, а также другие параметры социальной ситуации» [4].

Н.Д. Арутюнова дифференцирует понятия «текст» и «дискурс». Лингвист понимает текст как единицу языка наивысшего уровня, а дискурс - как текст, взятый в событийном аспекте, погруженный в ситуацию общения, как наблюдаемые проявления языка, как речь, погруженную в жизнь. Исходя из этого, термин дискурс, в отличие от термина текст, нельзя применить «к древним и другим текстам, связи которых с живой речью не восстанавливаются непосредственно» [1].

Исследователи Е.С. Кубрякова и О.В. Александрова осмысливают понятие «дискурс» в связи с понятиями «текст» и «речь». Дискурс является промежуточным звеном между речью как вербальным общением, с одной стороны, и конкретным текстом, зафиксированным в ходе общения, с другой стороны. Дискурс понимается как «когнитивный процесс, связанный с реальным речепроизводством, со знанием речевого произведения, а текст - как конечный результат процесса речевой деятельности, выливающийся в определенную законченную форму» [5].

Е.С. Кубрякова, исходя из дефиниции дискурса как речи, погруженной в жизнь (понимание Н.Д.Арутюновой), выделяет у дискурса наличие языкового аспекта, находящегося в тесном взаимодействии с социальнокультурологическими характеристиками: местом и временем осуществления дискурса, его типом, социальными задачами, стоящими перед говорящими [6]. Она выделяет когнитивную природу дискурса, поскольку именно когнитивная лингвистика изучает взаимодействие когнитивных и языковых структур. Дискурс как когнитивное языковое образование изучается в виде фреймов, сценариев, ментальных схем и других моделей репрезентации общения в сознании. 
Различные толкования дискурса влекут за собой соответствующие его типологии. Представляется целесообразным рассмотреть некоторые из них, получившие широкое освещение в научной лингвистической литературе.

Существует классификация событий по сфере общения. Так, выделяются следующие типы дискурса: научный, деловой, политический, конфессиональный, бытовой и др. [7].

Социолингвистический подход к исследованию дискурса предполагает анализ участников общения как представителей той или иной социальной группы и анализ обстоятельств общения в широком социокультурном контексте. С точки зрения социолингвистики В.И.Карасик предлагает выделять два основных типа дискурса: личностный и институциональный [8].

Первый случай предполагает, что говорящий раскрывает себя как личность, во втором типе общения - как представитель определенной социальной группы. Личностный (или персональный) дискурс представлен двумя основными разновидностями - бытовым (обиходным) и бытийным типами дискурса.

Специфика бытового дискурса детально отражена в исследованиях разговорной речи. Бытовой дискурс характеризуется зависимостью от ситуации, спонтанностью, нарушением структурного выражения высказывания. Общаясь на бытовом уровне, люди могут использовать сниженную и жаргонную лексику. Говорящий легко переходит от одной темы к другой, использует иронию, намеки и т.д., а адресату не требуется много времени, чтобы понять адресанта. Бытовой дискурс бывает прямым и опосредованным.

В прямом бытовом дискурсе В.И. Карасик выделяет два вида, противоположных друг другу: смысловой переход и смысловой прорыв. Смысловой переход определяется через рассуждения, через вербальное выражение чувств и мыслей, помогающее человеку определить неочевидные явления, которые имеют отношение к миру в целом. Смысловой прорыв осуществляется через внезапное понимание сути дела, ситуации, как озарение.

В опосредованном бытовом дискурсе предполагается символическое и переносное развитие идеи через повествование и описание. Повествование представляет собой последовательное изложение событий, описание статическую характеристику наблюдаемых, очевидных явлений. В повествовании и описании, в отличии от притчи, используются устойчивые социально-закрепленные смысловые связи и не требуется широкий культурный контекст.

Бытийный дискурс преимущественно монологичен и представлен в произведениях художественной литературы, а также в философских и психологических интроспективных текстах. В отличие от бытового, в бытийном дискурсе предпринимаются попытки раскрыть свой внутренний мир во всем его богатстве, общение носит развернутый, предельно насыщенный смыслами характер, используются все формы речи на базе литературного языка. Бытийный дискурс во многих отношениях противопоставлен бытовому, но оба дискурса 
имеют одно важное качество: в опоре на активное осмысление содержания речи со стороны адресата. Персональное общение строится на широком смысловом поле в сознании адресата, хотя природа расширения смыслов в бытовом и бытийном общении различна. В первом случае осознание смысла зависит от конкретной ситуации общения, во втором - от формы знака и личностной концептосферы адресата.

Институциональный дискурс представлен образцами вербального поведения, сложившимися в обществе применительно к закрепленным сферам общения [9]. С позиций социолингвистики можно выделить следующие виды институционального дискурса: политический, дипломатический, административный, юридический, военный, педагогический, религиозный, мистический, медицинский, деловой, рекламный, спортивный, научный, сценический и массово-информационный типы. Данный список может быть дополнен или видоизменен, «поскольку общественные институты существенно отличаются друг от друга и не могут рассматриваться как однородные явления, кроме того, они исторически изменчивы, могут сливаться друг с другом и возникать в качестве разновидностей в рамках того или другого типа» [8]. Институциональный дискурс - особая клишированная форма общения между людьми, которые могут не знать друг друга, но им надлежит общаться в соответствии с нормами данного социума. Существует интуитивно ощущаемая участниками общения граница, выход за которую нарушает основы существования того или иного общественного института. Институциональный дискурс обладает системообразующими признаками: целями и участниками общения. Например, цель политического дискурса - завоевание и удержание власти, педагогического дискурса - социализация нового члена общества, медицинского дискурса - оказание квалифицированной помощи больному и т.д. Основными участниками институционального дискурса являются представители института (агенты) и люди, обращающиеся к ним (клиенты): учитель и ученик, врач и пациент, политик и избиратель, священник и прихожанин. В.И.Карасик говорит также о разном уровне открытости дискурса. Например, клиенты в рамках научного, делового и дипломатического дискурса не отличаются от агентов, в то время как клиенты политического, юридического, медицинского, религиозного дискурса обнаруживают резкое отличие от агентов соответствующего дискурса.

Классификация личностного и институционального дискурса позволяет выделить некоторые особенности социокультурных ситуаций общения, типов личности и способов организации текста. 


\section{Литература}

1. Арутюнова Н. Д. Дискурс // Лингвистический энциклопедический словарь. - М.: «Советская энциклопедия», 1990. - С. 136-137.

2. Степанов, Ю.С. Альтернативный мир, Дискурс, Факт и принцип Причинности // Язык и наука конца 20 века. М. : Ин-т языкознания PAH, 1995.-С.35-73.

3. Дейк Т.А. ван, Кинч. В. Стратегии понимания связного текста/Пер. с англ. // Новое в зарубежной лингвистике. М., 1988. Вып. XXIII.

4. Дейк Т. А. ван. Язык. Познание. Коммуникация - М.: Прогресс, 1989. - 307c.

5. Кубрякова, Е.С. Язык пространства и пространство языка (к постановке проблемы) // Известия РАН. Сер. лит. и яз. 1997. - С.2231.

6. Кубрякова, Е.С. О термине «дискурс» и стоящей за ним структуре знания // Язык. Личность. Текст: сб. ст. к 70-летию Т.М. Николаевой / отв. ред. В.Н. Топоров. М. : Языки славянских культур, 2005. - С. 23-33.

7. Сухих С.А., Зеленская В.В. Прагмалингвистическое моделирование коммуникативного процесса. - Краснодар, 1998.- 160 с.

8. Карасик, В.И. О типах дискурса // Языковая личность: институциональный и персональный дискурс: Сб. науч. тр. Волгоград: Перемена, 2000. - 5-20 с.

9. Карасик В. И. Общие проблемы изучения дискурса //Языковая личность: институциональный и персональный дискурс. Волгоград: Перемена, 2000. - С. 5-20. 